\title{
COREFSPONDEINOF.
}

\section{FLINTS FROM THE SUFFOLK BONE BED.}

SIR,-On p. 64 of a recently published paper, entitled "Flints" (Cambridge Antiquarian Society's Communications, vol. xviii), Professor McKenny Hughes, F.R.S., in dealing with the question of the sub-Crag flint implements I have discovered, makes the following statement: "Mr. Reid Moir has long been trying to test this question by observation and experiment, and has arrived at the conclusion that nature does not produce the forms in question. I must, however, say that I have failed to arrive at the same conclusion, but find that identical forms are produced under shore conditions which must have been similar to those under which the Suffolk Bone Bed was laid down." The definite nature of this statement induced me to pay a visit to the Sedgwick Museum, Cambridge, to see and handle these flints, flaked under present-day shore conditions, which were said to be "identical" with the sub-Crag specimens-a typical series of which I took with me for comparison. The examination of Professor Hughes' beach specimens showed me at once that none of the forms labelled "Bec d'aigle" bore any real resemblance to the rostro-carinate specimens recovered from the Suffolk Bone Bed, and represented obviously naturally broken flints which no one familiar with the sub-Crag specimens could ever regard as in any way similar, and the same may with confidence be stated of the beach examples purporting to represent other sub-Crag forms. I have no wish to say any harsh thing about Professor Hughes, for whom I entertain a great respect and regard, but $I$ think he has been unwittingly misleading by his misuse of the word "identical" in his paper, and that it is not quite fair to Sir Ray Lankester and me-and liable to fog the issue-to label specimens in the Sedgwick Museum "Bec d'aigle" which bear no real resemblance to the sub-Crag rostro-carinate specimens.

12 St. EDMUND's ROAD,

J. REID MoIr. IPSWICH.

\section{GUIDE TO THE FOSSIL REMAINS OF MAN IN THE BRITISH MUSEUM. ${ }^{1}$}

SIR,-I have read with much interest the review of the Guide to the Fossil Remains of Man in the British Museum, published in the Geological Magazine. Would it not be possible in the second edition to allow the Neanderthal man (as shown in fig. 12) a scapula? Such an omission is sure to lead to some silly mistakes on the part of the general public, for whom I presume this guide is written.

Fisherton de LA Mere House,

R. S. NewatL.

WYLYE, WIITS.

March 15, 1915.

1 See Geol. Mag. for March, 1915, p. 129. 